\title{
A Case of Angioleiomyoma Arising from the Right Inferior Turbinate
}

\author{
Jae-Hong Aum, Seung-Wook Han, and Il-Gyu Kang \\ Department of Otorhinolaryngology Head \& Neck Surgery, Gacheon University, Gil Medical Center, Incheon, Korea
}

\section{우측 하비갑개에서 발생한 혈관평활근종 1예}

엄재홍 · 한승욱 · 강일규

가천대학교 길병원 이비인후-두경부외과

\author{
Received July 18, 2014 \\ Revised August 19,2014 \\ Accepted August 19, 2014 \\ Address for correspondence \\ Il-Gyu Kang, MD, PhD \\ Department of Otorhinolaryngology \\ Head \& Neck Surgery, \\ Gacheon University, \\ Gil Medical Center, \\ 21 Namdong-daero 774beon-gil, \\ Namdong-gu, Incheon \\ 405-760, Korea \\ Tel $+82-32-460-3324$ \\ Fax +82-32-467-9044 \\ E-mail eyik@naver.com
}

Leiomyoma is a benign smooth muscle neoplasm that rarely becomes malignant. It can occur in any organ of the human body that contains smooth muscles, but the most common forms occur in female genitourinary organs, including the uterus, gastrointestinal organs, including the small bowel and the esophagus and the skin. It rarely occurs in the head and neck area, including the sinonasal cavity. When it occurs in the nasal cavity, its clinical symptoms include nasal obstruction, nasal discharge, nasal bleeding, and pain. We describe herein a case of a 55-year-old man with a leiomyoma in his right inferior nasal turbinate. Transnasal endoscopic excision and paranasal sinus CT were performed. A soft tissue mass on the right inferior turbinate was confirmed from the paranasal sinus CT, and the pathological results revealed a vascular leiomyoma.

Korean J Otorhinolaryngol-Head Neck Surg 2015;58(5):355-8

Key Words Inferior turbinate $\cdot$ Leiomyoma $\cdot$ Nasal cavity.

\section{서 론}

평활근종은 신체에서 평활근이 존재하는 곳에서 발병할 수 있지만 그중에서도 자궁을 비롯한 여성생식기계에서 가장 흔하게 발병하고, 그 외에 피부, 소화기계, 피하조직 등에서 호 발하는 양성의 종양이다. ${ }^{1)}$ 남성에 비해 여성에서 2배 정도 많 은 빈도로 호발하며, 주로 50대에서 60대의 중년 및 노년기에 많이 발병한다는 역학적인 특징이 있다. ${ }^{2)}$ 상기 언급한 부위 이외에는 매우 드물게 나타나며, 그중에서도 비강에서는 매우 희박한 빈도로 나타나는 것이 특징인데, 이는 상기 부위에 평활근 섬유가 많이 분포하지 않는다는 점에 기인한다. ${ }^{3)}$ 조직 학적으로 단순 평활근종, 혈관성 평활근종, 그리고 상피성 평 활근종의 3 가지 아형으로 분류되며, 비강 내 평활근종의 경우 수술적 절제가 가장 근본적인 치료이다.,2) 본 저자들은 수개 월에 걸쳐서 서서히 나타난 비폐색을 주소로 내원하였다가 우측 비강 내에서 발병한 혈관성 평활근종으로 진단받은 환자
1예를 문헌고찰과 함께 보고하고자 한다.

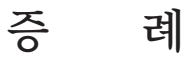

55세의 남자 환자가 내원 수개월 전부터 시작된 지속적인 우측 비강의 통증 및 불편감을 주소로 내원하였다. 통증은 쿡쿡 쑤시는 양상이었고 이물감도 동반되었다. 과거력상에서 특이 소견은 보이지 않았다. 비강내시경 검사상 비중격의 우측 만곡 외에 우측 하비갑개의 하연, 하비도에 종물이 관찰되었다 (Fig. 1). 그 외에 비인두, 구강, 후두 및 경부 등 다른 신체검사 상에서는 별다른 특이 소견은 보이지 않았다.

종물은 표면이 매끄럽고 경계가 명확한 구형으로 $0.5 \times 0.5 \mathrm{~cm}$ 크기였으며 우측 하비갑개 하연에 부착되어 있는 양상이었다. 종물의 크기 및 파급범위에 관한 추가적인 평가를 위해 부비 강의 조영증강 전산화단층촬영검사(paranasal sinus $\mathrm{CT}$ )를 시행하였다. CT 검사 결과 우측 하비갑개 아래측에 관찰되는 
약 $0.5 \times 0.5 \mathrm{~cm}$ 크기의 작은 종물이 확인되었고, 그 외에 양측 상악동 부비동염 소견 및 비중격의 우측 편위가 보였다(Fig. 2). 이러한 영상학적인 결과를 바탕으로 정확한 진단을 위해서



Fig. 1. Small reddish mass (arrow) seen on the right inferior meatus through nasal endoscopy.

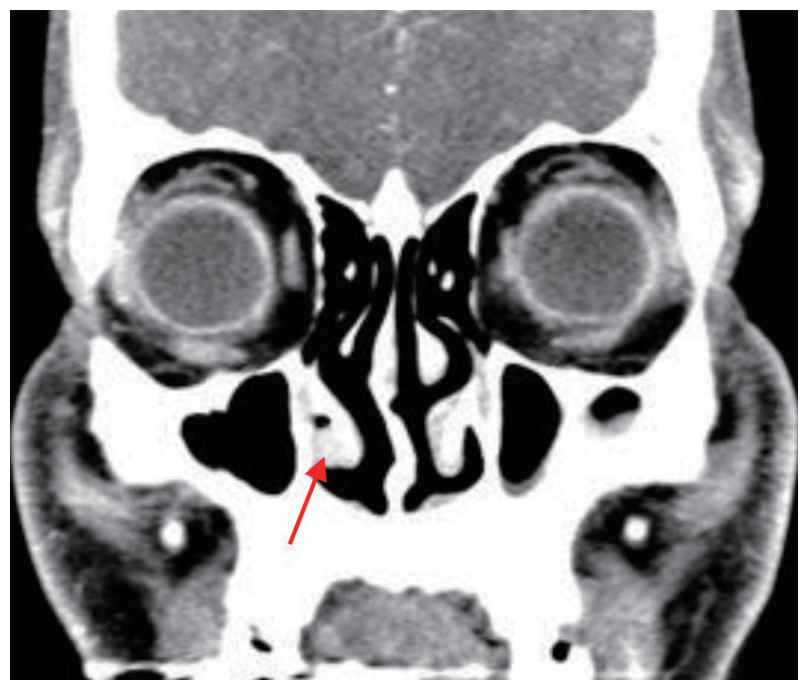

Fig. 2. Paranasal sinus CT coronal view that revealed a $0.5 \times 0.5 \mathrm{~cm}$ soft tissue mass (arrow) that originated in the right inferior turbinate.
CT 검사를 시행한 당일 외래에서 국소마취 하에 비강내시경 을 통한 병리조직검사를 시행하였다. 조직검사는 단순한 펀 치생검이 아닌, 우측 하비갑개 하연에 부착된 종물 전체를 절 제하는 절제생검을 시행하였다. 종물의 기시부를 포함하여 정상 점막 부위까지 완전히 절제하였고 다량의 출혈은 없었 다. 검사 시행 4일 뒤에 나온 병리조직검사 결과로는 혈관성 평활근종으로 판명되었다.

병리조직검체는 하비갑개에서 절제한 종물이며, 붉은색을 띤 연조직 양상으로 크기는 $0.7 \times 0.5 \times 0.2 \mathrm{~cm}$ 였다. 조직학적 으로는 방추형의 평활근 세포의 다발이 여러 방향으로 들어오 고 있었으며 주위와의 경계는 비교적 명확하였다. 종괴에는 두 터운 벽을 지닌 혈관, 그 주위를 둘러싸고 있는 방추형의 세 포, 그 외에 세포핵 및 호산성의 세포질 등이 관찰되었다(Fig. 3). 상환은 영상의학적 검사와 절제생검 시행 후 재발 없이 추적 관찰 중이다.

\section{고 찰}

평활근종은 평활근이 존재하는 곳이라면 신체 어디에서 든지 발병할 수 있는 양성 종양이며, 일반적으로 크기가 작 고 무통성인 경우가 많다. ${ }^{3)} 1854$ 년 Virchow에 의해서 최초로 서술되었으며 1884년 Blanc에 의해 처음으로 보고되었다.")

신체에서 가장 호발하는 부위는 자궁을 비롯한 여성생식 기계이며, 전체의 $95 \%$ 를 차지하고, 그 외에 피부(3\%), 소화기계 $(1.5 \%)$ 등의 순으로 나타난다. ${ }^{1)}$ 두경부에서 나타나는 경우에는 입술(27.46\%), 혀(18.30\%), 볼 점막, 연구개 및 경구개 순으로 발 병하지만, 그 전체 빈도는 매우 드물어 전체 평활근종의 $1 \%$ 미만에 불과하다. ${ }^{4)}$ 두경부에서 나타나는 경우 중에서도 오직 $3 \%$ 정도만이 하비갑개, 비전정, 비중격, 중비갑개 등 비강 내 에서 발병한다. ${ }^{2)}$ 1966년 Maesaka 등에 의하여 최초의 비강 내 평활근종이 보고된 이래로 영어권 지역에서 현재까지 60여 증례만이 보고되고 있을 정도로 드문 빈도를 보인다. ${ }^{5)}$ 이는 상 기 부위에 평활근 섬유가 극히 드물게 존재하기 때문에, 종물 이 나타나고 성장할 수 있는 환경이 마련되어 있지 않은 것에
Fig. 3. Thick-walled vessels and surrounding spindle cells seen through H\&E staining (magnification, $\times 40)(A)$ and spindle cells with an eosinophilic cytoplasm, perinuclear vacuoles, and vesicular nuclei seen through $\mathrm{H} \& \mathrm{E}$ staining (magnification, $\times 200)(B)$.
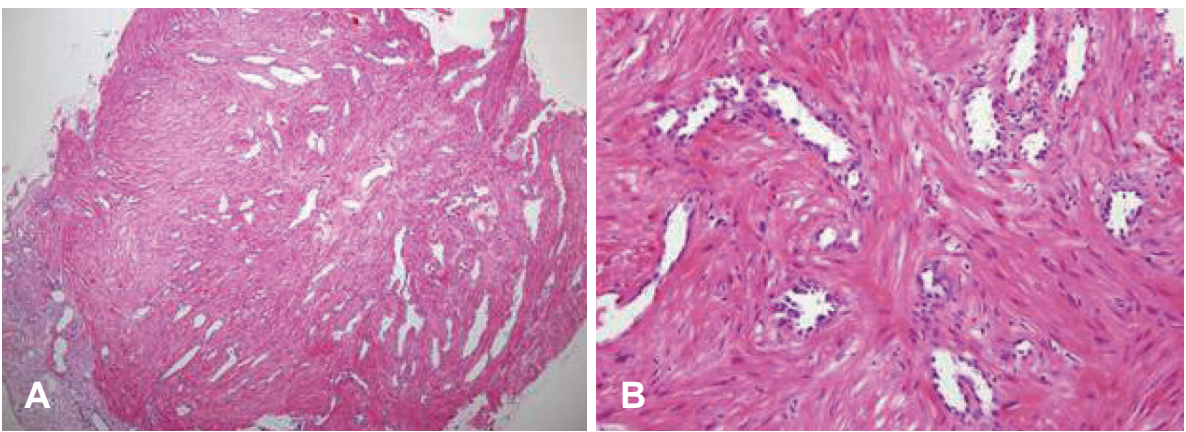
기인한다. ${ }^{3)}$ 비강에서 발병하는 경우에는 다량의 혈관조직을 함유하고 있는 하비갑개에서 가장 호발한다고 알려져 있다.)

평활근종의 병인에 관하여는 아직 정확하게 밝혀지고 정 립된 이론은 없으나, 혈관벽의 평활근에서 유래되었다는 가설 이 가장 유력하게 받아들여지고 있으며, 또한 평활근종이 프 로게스테론을 비롯한 호르몬 의존성을 지니고 있다는 가설 이 있는데, 이는 평활근종이 남성에서보다 여성에서 훨씬 더 많이 나타나며, 가장 호발하는 부위가 자궁을 비롯한 여성 생식기계이고, 특히 자궁 평활근종의 경우 임신이나 월경 기간 에 크기가 증가하고 통증 등 증상이 심해지는 것에서 그 근거 를 찾을 수 있다. ${ }^{2}$

세계보건기구(World Health Organization)는 평활근종을 크게 3 가지의 아형으로 분류하였는데 단순 평활근종, 혈관 근육종(혈관성 평활근종), 그리고 상피성 평활근종(평활근모세 포종)으로 나뉜다. ${ }^{1}$ 그중에서도 혈관성 평활근종이 가장 높은 빈도를 보인다. ${ }^{2}$ 1973년 Morimoto는 다시 조직학적으로 3가지 유형으로 나누었으며, 이는 고형(solid) 또는 모세혈관성(capillary) 평활근종, 해면상(cavernous) 평활근종, 그리고 정맥성 (venous) 평활근종이다. 혈관성 평활근종 중에서 두경부에 나 타나는 경우는 전체의 $8.5 \%$ 에 불과하며, 비강을 비롯한 두경 부에서 나타나는 경우 보통 $2 \mathrm{~cm}$ 이하의 작은 크기를 보인다. ${ }^{7)}$ 본 증례는 55 세 남환의 우측 하비갑개에서 나타난 $0.5 \times 0.5 \mathrm{~cm}$ 정도의 작은 크기였고 종괴 내에 혈관이 관찰되는 양상이었 으며 실제로 병리조직검사 결과상 혈관성 평활근종으로 판명 되어, 나이, 종물의 크기, 조직학적인 아형 등에서 거의 전형적인 비강 내 평활근종의 특징을 보였다.

평활근종은 느린 속도로 성장하는 종양이며, 비강 내에서 발병할 경우 흔히 나타나는 증상으로는 비출혈(56.25\%) 및 비 폐색(56.25\%), 안면통증(25\%) 및 두통(25\%) 등이 있다. ${ }^{1,8)}$ 비폐 색은 종괴의 팽창효과로 인하여, 안면통과 두통은 부비동 환 기 및 점막섬모운동의 장애에 기인한다. ${ }^{9)}$ 그 외에 종괴 자체의 압박효과로 인하여 골미란, 국소적인 종괴 파급 등도 보일 수 있다. ${ }^{5)}$

평활근종의 정확한 진단을 위해서는 병리조직검사가 필수 적이며, CT 등 영상의학적 검사가 종괴의 크기 및 파급범위, 또는 골미란 여부 등의 정보를 파악하거나 치료계획을 수립 하기 위해 요구되는 경우가 있다. ${ }^{1)}$ 평활근종은 본 증례와 마찬 가지로, 병리조직학적으로 섬유상 다발 형태의 방추 모양의 세 포와 여송연 모양(cigar shape)의 세포핵이 나타나는 것이 보통 이다. ${ }^{2,3,5)}$ 일반적으로 hematoxylin \& eosin 염색법이 많이 이용 되며, $\mathrm{CD} 31$ 등을 비롯한 면역조직학적인 방법이 요구되는 경우 가 많다.') 이와 같이 평활근종의 정확한 진단을 위해서는 면 역조직화학적인 검사가 요구된다. ${ }^{3)}$
비강 내 평활근종의 치료에 있어서는 수술적 절제가 가장 확실한 치료법이다. ${ }^{2)}$ 특히 완벽한 절제가 이루어진 경우 재발 은 극히 드물게 나타난다고 알려져 있다.5) 혈관성인 경우에 도 절제한다고 해서 대량출혈이 나타나는 경우는 드물다.,7) 술 전 영상의학적 검사를 통하여 종괴의 크기와 위치, 파급범 위 등을 파악함으로써 수술 시 접근법을 결정할 수 있으며, 집도의의 경험도 수술의 방식에 영향을 줄 수 있다. ${ }^{2,5)}$ 그중 에서도 $\mathrm{CT}$ 검사가 종괴의 파급범위, 골미란 여부를 파악하 고 가장 적합한 수술적 접근법을 판단하기 위해 필요하다. ${ }^{6}$ 특히 혈관성 아형일수록 조직검사 시행 중 나타날 수 있는 대 량출혈 등의 가능성 때문에 미리 대비가 필요하다. ${ }^{10)}$ 가령 수술 전 선택적 전색술(selective embolism) 등이 그 방편이 될 수 있 다. ${ }^{11)}$ 본 증례는 혈관성 아형이면서 종물의 크기도 작은 편이 었기 때문에, 먼저 CT를 시행하여 이를 통해서 종물의 정확한 위치 및 범위 등을 확인하였고, 당일 외래에서 조직검사를 시 행하였다. 수술적인 접근법에는 크게 내시경적 접근법, 가측 비개방술, Caldwell-Luc 접근법 등이 있다. ${ }^{2}$ 최근에는 내시 경적 접근법이 가장 유용하게 쓰이고 있다. ${ }^{5)}$

결론적으로, 평활근종은 혈관 평활근 섬유의 결여 때문에 두경부, 특히 비강에서는 매우 드물게 나타나며, 발병 시 나타 나는 증상으로는 비출혈, 비폐색, 통증 등이 있다. 병리조직검 사를 통해 확진을 하고, 영상의학적 검사를 통해 추가적인 평 가 및 치료계획 수립을 할 수 있으며, 내시경적 접근법 등을 통 한 수술적 절제가 가장 확실한 치료법이라고 할 수 있다.

저자들은 국내뿐만 아니라 전 세계적으로도 드물게 보고 되고 있는 비강 내 평활근종의 증례가 새롭게 추가되었다는 사 실 이외에도, 혈관성 평활근종이라는 가장 흔한 아형, 직경 1 $\mathrm{cm}$ 도 안 되는 작은 크기, 역학적으로 중년의 나이라는 호발 조건을 지녔다는 점과 비폐색 등 증상을 보인다는 특징들이 현재까지 보고된 비강 내 평활근종의 전형적인 예와 유사한 모습을 보여준다는 면에서 임상적인 의의가 있다고 사료되어 문헌고찰과 함께 보고하는 바이다.

\section{REFERENCES}

1) Campelo VE, Neves MC, Nakanishi M, Voegels RL. Nasal cavity vascular leiomyoma: case report and literature review. Braz $\mathrm{J}$ Otorhinolaryngol 2008;74(1):147-50.

2) Tseng PY, Lai YS, Chen MK, Shen KH. Progesterone receptor expression in sinonasal leiomyoma: a case report and review of the literature. Int J Clin Exp Pathol 2014;7(3):1224-8.

3) Meher R, Varshney S. Leiomyoma of the nose. Singapore Med J 2007; 48(10):e275-6.

4) Veeresh M, Sudhakara M, Girish G, Naik C. Leiomyoma: a rare tumor in the head and neck and oral cavity: report of 3 cases with review. J Oral Maxillofac Pathol 2013;17(2):281-7.

5) Agarwal AK, Bansal R, Singhal D. Sinonasal leiomyoma: report of 2 cases. Ear Nose Throat J 2005;84(4):224, 226-30.

6) Michael RC, Shah S. Angioleiomyoma of the nasal cavity. Indian J 
Pathol Microbiol 2009;52(3):386-8.

7) Yoon TM, Yang HC, Choi YD, Lee DH, Lee JK, Lim SC. Vascular leiomyoma in the head and neck region: 11 years experience in one institution. Clin Exp Otorhinolaryngol 2013;6(3):171-5.

8) Navarro Júnior CR, Fonseca AS, Mattos JR, Andrade NA. Angioleiomyoma of the nasal septum. Braz J Otorhinolaryngol 2010;76(5):675.
9) Cintra PP, Lima WT, Rodrigues Junior A. Leiomyoma of the nasal cavity: case report. Braz J Otorhinolaryngol 2007;73(6):851.

10) Lim SJ, Park YK, Kim HJ. A case of angioleiomyoma of nasal septum. Korean J Otorhinolaryngol-Head Neck Surg 2014;57(5):337-9.

11) Lee HM, Kim JM, Chu HS, Lee SH. A case of angiomyoma of the inferior turbinate. Korean J Otolaryngol-Head Neck Surg 2002;45 (12):1193-5. 